\title{
Antidiabetic effects of chitooligosaccharides on pancreatic islet cells in streptozotocin-induced diabetic rats
}

\author{
Bing Liu, Wan-Shun Liu, Bao-Qin Han, Yu-Ying Sun
}

\begin{abstract}
Bing Liu, Wan-Shun Liu, Bao-Qin Han, Yu-Ying Sun, Department of Marine Life Science, Ocean University of China, Yushan Road, No. 5, Qingdao, Shandong Province, China

Supported by the National High Technology Research and Development Program of China (863 Program, 2001AA625050) and the National Key Research and Development Program of China during the Tenth Five-Year Plan Period, No. 2001BA708B04-07

Correspondence to: Wan-Shun Liu, College of Marine Life Science, Ocean University of China, Qingdao 266003, Shandong Province, China. iceicecream1221@126.com

Telephone: +86-532-82032105 Fax: +86-532-82032105

Received: 2006-11-11

Accepted: 2006-11-29
\end{abstract}

\begin{abstract}
AIM: To investigate the effect of chitooligosaccharides on proliferation of pancreatic islet cells, release of insulin and $2 \mathrm{~h}$ plasma glucose in streptozotocin-induced diabetic rats.

METHODS: In vitro, the effect of chitooligosaccharides on proliferation of pancreatic islet cells and release of insulin was detected with optical microscopy, colorimetric assay, and radioimmunoassay respectively. In vivo, the general clinical symptoms, $2 \mathrm{~h}$ plasma glucose, urine glucose, oral glucose tolerance were examined after sixty days of feeding study to determine the effect of chitooligosaccharides in streptozotocin-induced diabetic rats.

RESULTS: Chitooligosaccharides could effectively accelerate the proliferation of pancreatic islet cells. Chitooligosaccharides $(100 \mathrm{mg} / \mathrm{L})$ had direct and prominent effect on pancreastic $\beta$ cells and insulin release from islet cells. All concentrations of chitooligosaccharides could improve the general clinical symptoms of diabetic rats, decrease the $2 \mathrm{~h}$ plasma glucose and urine glucose, and normalize the disorders of glucose tolerance.
\end{abstract}

CONCLUSION: Chitooligosaccharides possess various biological activities and can be used in the treatment of diabetes mellitus.

(C) 2007 The WJG Press. All rights reserved.

Key words: Chitooligosaccharides; Diabetes mellitus; Two hours plasma glucose; Oral glucose; Tolerance test; Pancreastic islet cells; Streptozotocin

Liu B, Liu WS, Han BQ, Sun YY. Antidiabetic effects of chitooligosaccharides on pancreatic islet cells in streptozotocin-induced diabetic rats. World J Gastroenterol 2007; 13(5): 725-731

http://www.wjgnet.com/1007-9327/13/725.asp

\section{INTRODUCTION}

Diabetes mellitus (DM) is a highly prevalent disease all over the world. Its long-term tissue complications that affect small and large blood vessels are directly connected with the time of patients suffering from hyperglycemia. Chitosan is a polycationic copolymer consisting of $\beta$-1, 4-linked 2-acetamido- D-glucose and $\beta$-1, 4-linked 2 -amino-D-glucose units. Crab and shrimp shell wastes are currently utilized as the major industrial source of biomass for large-scale production of chitosan. Chitosan which is biodegradable, non-toxic and biocompatible has been shown to be particularly useful in many fields ${ }^{[1]}$, including food, cosmetics, biomedicine, agriculture and environmental protection. Furthermore, it can be used as a bioactive material due to its biodegradable, non-toxic and non-allergenic natures. However, chitosan shows its biological activity only in acidic medium because of its poor solubility at $\mathrm{pH}$ above 6.5 and low absorbability of non-digestible and high molecular polysaccharides. Therefore, recent studies on chitosan have attracted interest in converting it to chitooligosaccharides(COS), because COS not only are water-soluble but also possess versatile functional properties such as antitumor enhancing properties $^{[2,3]}$, immunostimulating effects ${ }^{[2,4]}$, antimicrobial activity $^{[5]}$, free radical scavenging activity ${ }^{[6-8]}$, protective effects against infections ${ }^{[0]}$, arthritis controlling activity ${ }^{[10]}$, plant disease controlling activity ${ }^{[11,12]}$ and angiotensin I converting enzyme inhibitory activity ${ }^{[13]}$. However, little attention has been paid to its activity in diabetes mellitus and related mode of action.

In the present study, soluble chitooligosaccharides with low molecular weight were prepared by enzymatic hydrolysis of chitosan with chitosanase as previously described ${ }^{[14]}$. The purpose of this study was to examine the effect of chitooligosaccharides on proliferation of pancreatic islet cells and release of insulin in vitro.

\section{MATERIALS AND METHODS}

\section{Materials}

Chitosan (minimum 90\% deacetylated, $M_{\mathrm{r}}: 500000$ ) was purchased from Jinan Haidebei Marine Bioengineering 
Co., Ltd (Shangdong, China). Chitooligosaccharides were prepared by enzymatic hydrolysis of chitosan with chitosanase. NIT-1 cell line was from Institute of Medicine, Ocean University of China. Male Wistar rats (200 $\pm 20 \mathrm{~g}$ ) were from Laboratory Animal Centre, Institute of Medicine, Ocean University of China. Streptozotocin (STZ) was from Sigma Chemical Co. Tissue-culture medium and reagents were from Gibco. All chemicals were purchased from Sigma Chemical unless otherwise stated.

\section{Cell culture}

Rat islets were isolated from the pancreas of male Wistar rats by collagenase digestion as previously described ${ }^{[15,16]}$ and dispersed into single cells by shaking in a low calcium medium ${ }^{[17]}$. The viability of cells after isolation, determined using the fluorochrome-media-ted viability test (see below) was $\geqslant 98 \%$. The islets were placed on glass coverslips in $35-\mathrm{mm}$ petri plates and cultured in RPMI-1640 medium containing 20\% fetal bovine serum (FBS), L-glutamine, and penicillin/streptomycin. NIT-1 cell line, a widely used $\beta$ cell line for insulin secretion studies, was established from non-obese diabetic (NOD) mice transgenic for the SV40 $\mathrm{T}$ antigen under control of the insulin promoter, and cultured in DMEM containing 10\% FBS and antibiotics $(100 \mathrm{IU} / \mathrm{mL}$ of penicillin and $100 \mu \mathrm{g} / \mathrm{mL}$ of streptomycin). All cultures were kept at $37^{\circ} \mathrm{C}$ in $950 \mathrm{~mL} / \mathrm{L}$ $\mathrm{O}_{2}$ and $50 \mathrm{~mL} / \mathrm{L} \mathrm{CO}_{2}$. The medium was changed every two days. The islet cells cultured under these conditions spread out as a monolayer within $14 \mathrm{~d}$ and exhibited normal responses of insulin release to glucose stimulation, as described in previous studies ${ }^{[18,19]}$.

\section{Effects of COS on proliferation of pancreastic islet cells and insulin release}

COS were dissolved in Dulbecco's modified Eagle's medium (DMEM) without FBS and then diluted with medium to form the five degrades $(10,100,500,1000$, and $2000 \mathrm{mg} / \mathrm{L})$. The structure and function of cultured islet cells were observed under inverted phase contrast microscope. MTT assay was used to estimate the cell viability. Pancreastic islet cells were digested by $0.25 \%$ trypsin until appearance of unicellular suspension. Then $100 \mu \mathrm{L}$ suspension with the concentration of $5.0 \times 10^{4}$ cells $/ \mathrm{mL}$ was transplanted into 96-well plates. Each well had three parallels. After incubated for $24 \mathrm{~h}$, the medium was changed with COS at different concentrations. Cells were incubated with 0.5 $\mathrm{mg} / \mathrm{mL}$ of MTT in the last $4 \mathrm{~h}$ of the culture period (48 h). The medium was then decanted, $200 \mu \mathrm{L}$ DMSO was added to the wells, and the absorbance was determined at $492 \mathrm{~nm}$ using an ELISA reader. The proliferation rate was calculated $(\mathrm{PR}=\mathrm{A} / \mathrm{A} 0 \times 100 \%)$. Furthermore, the effect of $\operatorname{COS}$ on the viability of pancreastic islet cells was also examined at 12, 24, 36, 48, 60, 72, 96, 120, 144, 168, 192 and $216 \mathrm{~h}$ to study the effect of COS on the growth phase of pancreastic islet cells in $9 \mathrm{~d}$. At the same time, freshly dispersed islet cells were transplanted into 24 -well plates at the concentration of $5.0 \times 10^{4}$ cells $/ \mathrm{mL}$, then divided into groups and stimulated with $100 \mathrm{mg} / \mathrm{L}$ COS for $14 \mathrm{~d}$. The incubation medium was collected every $2 \mathrm{~d}$ and then stored at $-20^{\circ} \mathrm{C}$ until assay. Control group was maintained in basal RPMI 1640. Each well had five parallels. At the end of the stimulation period, insulin was measured using

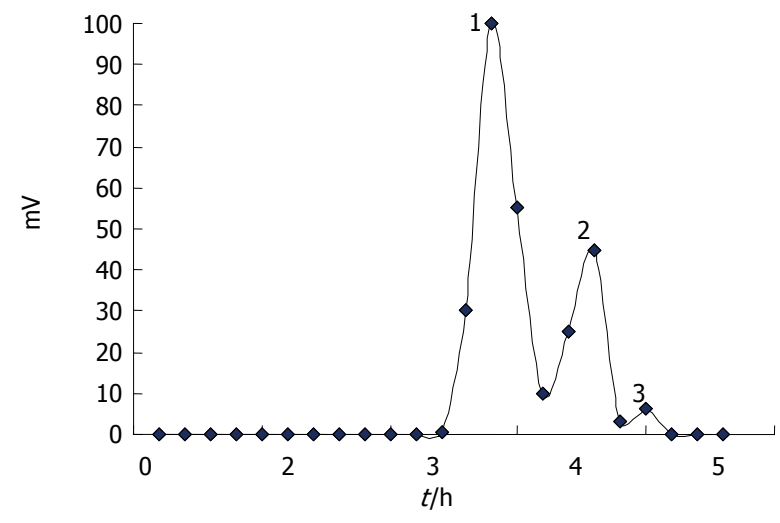

Figure 1 Chromatogram of chitooligosaccharids on Sephadex G-25 colum.

a radio-immunoassay kit for human insulin from Linco. The experiments were performed in triplicate.

\section{Effect of COS on streptozotocin-induced diabetic rats}

Male Wistar rats were rendered diabetic by intraperitoneal injection of STZ at $65 \mathrm{mg} / \mathrm{kg}$. The rats whose fasting blood glucose level was above $11.11 \mathrm{mmol} / \mathrm{L}$ were used for experiments after seven days. Then the rats were randomly divided into metformin treatment group, positive control group (DM) and COS treatment groups. Test samples were given intragastrically by gavage needle for 60 successive days. COS treatment groups were given chitooligosaccharides at the concentration of 250 , $500,1500 \mathrm{mg} / \mathrm{kg}$ daily. Normal control group and DM group received an equal volume of distilled water about $10 \mathrm{~mL} / \mathrm{kg}$. Metformin treatment group was given metformin at a concentration of $200 \mathrm{mg} / \mathrm{kg}$ daily. Two-hour plasma glucose (2hPG) and urine glucose were measured every $10 \mathrm{~d}$. Oral glucose tolerance was examined after $60 \mathrm{~d}$ of feeding study. Plasma glucose was immediately measured in duplicate using a Beckman glucose analyzer II (Beckman, Palo Alto, CA).

\section{Statistical analysis}

ANOVA was performed with Duncan's multiple range tests. SAS was used to compare the means (SAS Institute, Inc., Cary, NC, USA). $P<0.05$ was considered statistically significant, $P<0.01$ was considered very statistically significant.

\section{RESULTS}

\section{Physicochemical properties and HPLC analysis of chitooligosaccharides}

Chitooligosaccharides were prepared by enzymatic hydrolysis of chitosan. Components of the hydrolysis product were separated by Sephadex G-25 (Figure 1), and component 1 analyzed by TSK-GEL G3000PWXL had an average molecular weight of $1200 \mathrm{u}$, and a degree of deacetylation of $90 \%$ by the first derivative method of UV spectrometry.

\section{Effects of COS on proliferation of pancreastic islet cells and insulin release}

The influence of COS on pancreastic islet cell viability 


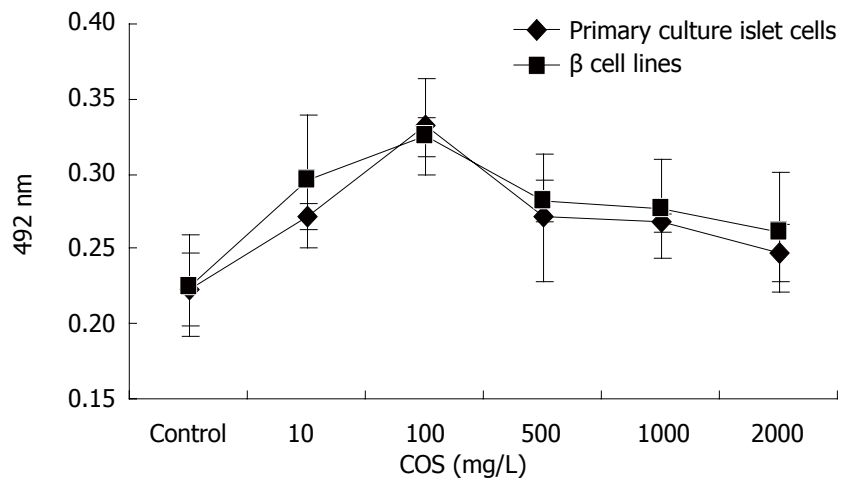

Figure 2 Effect of COS on proliferation of primary culture islet cells and $\beta$ cell lines.

was assessed by MTT assay (Figure 2). Cell viability in the presence of different concentrations of COS was significantly higher than that in the absence of different concentrations of COS. The maximum stimulatory effect on cell viability was achieved at $100 \mathrm{mg} / \mathrm{L}$ concentration among the five samples (Figures $3 \mathrm{~A}$ and $\mathrm{B}$ ), the proliferation rate was $148.43 \%$ and $143.71 \%$ respectively, and had a significant difference compared with the nomal control group (Figures $3 \mathrm{C}$ and $\mathrm{D}, P<0.01$ ), suggesting that COS could accelerate the proliferation of pancreastic islet cells in $9 \mathrm{~d}$, and exert direct effects on pancreastic $\beta$ cells, promote the growth of pancreastic islet cells to maximal density in $72 \mathrm{~h}$, decease the time of latent phase and logarithm growth phase of pancreatic $\beta$ cells (Figure $4 \mathrm{~A})$. The maximum stimulatory effect on cell growth phase was also achieved at $100 \mathrm{mg} / \mathrm{L}$ concentration among the five samples $(P<0.01)$

As can be seen in Figure 4B, the results showed that exposure of primary cultured pancreatic cells to COS (100 $\mathrm{mg} / \mathrm{L}$ ) could continuously increase the secretion of insulin from the $6^{\text {th }}$ to the $14^{\text {th }}$ day, and had a significant difference compared with the normal control group $(P<0.05)$.

\section{Effect of COS in streptozotocin-induced diabetic rats}

All concentrations of chitooligosaccharides could decrease the $2 \mathrm{hPG}$ in $60 \mathrm{~d}$ (Figure 4C), the best effect was observed in the $500 \mathrm{mg} / \mathrm{kg}$ treatment group, with the $2 \mathrm{hPG}$ decreased to $16.14 \mathrm{mmol} / \mathrm{L}$. The decrease rate was $47.48 \%$ compared with $2 \mathrm{hPG}$ before treatment.

The test of glucose tolerance was used to further evaluate the effects of different concentrations of chitooligosaccharides on improving the sensitivity of insulin. AS shown in Figure 4D, if the area under the DM group curve was regard as $100 \%$, then AUC of the normal control group accounted for only 17.69\% AUC of the DM group, while all concentrations of chitooligosaccharides could decrease AUC (Table 1). The best effect was observed in the medium dosage $(500 \mathrm{mg} / \mathrm{kg})$ treatment group, accounting for $68.69 \%$ of the area under the DM group curve $(P<0.01)$.

\section{DISCUSSION}

COS possess various biological activities and can be used in a number of industries. Unlike high molecular
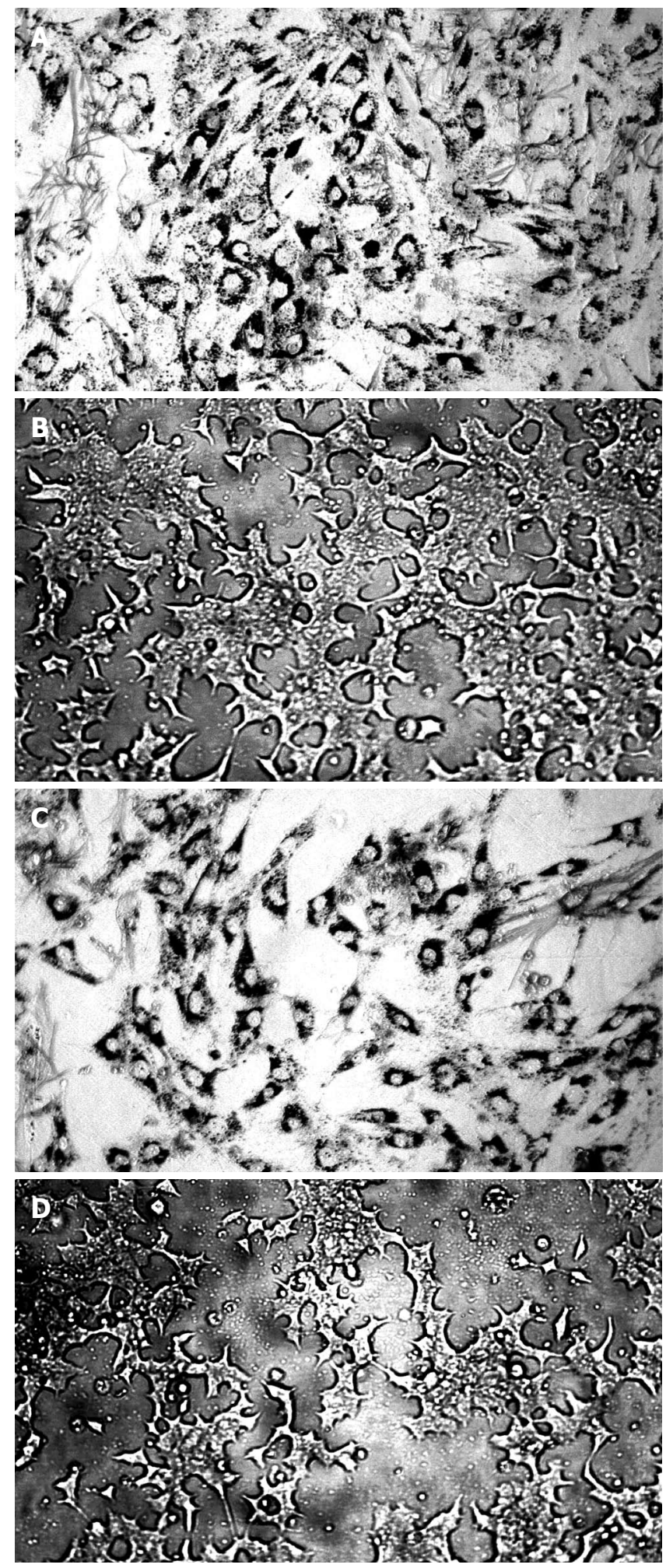

Figure 3 Photomicrograph of $\operatorname{COS}$ on the $48 \mathrm{~h}$ proliferation of pancreatic islet cells and $\beta$ cells $(\times 100)$ in control group $(A)$ and $100 \mathrm{mg} / \mathrm{L} \mathrm{COS} \mathrm{treatment} \mathrm{group} \mathrm{(B)} \mathrm{of}$ pancreatic islet cells, control group (C) and $100 \mathrm{mg} / \mathrm{L} \mathrm{COS} \mathrm{treatment} \mathrm{group} \mathrm{(D)} \mathrm{of}$ $\beta$ cell lines.

weight chitosan, COS which are readily soluble in water due to their shorter chain and free amino groups in D-glucosamine units and easily absorbed through the intestine, can quickly get into the blood flow and have systemic biological effects in the organism. In food industry, COS attract a greater interest as antimicrobial agents, antioxidants and enhancers of nutritional quality 

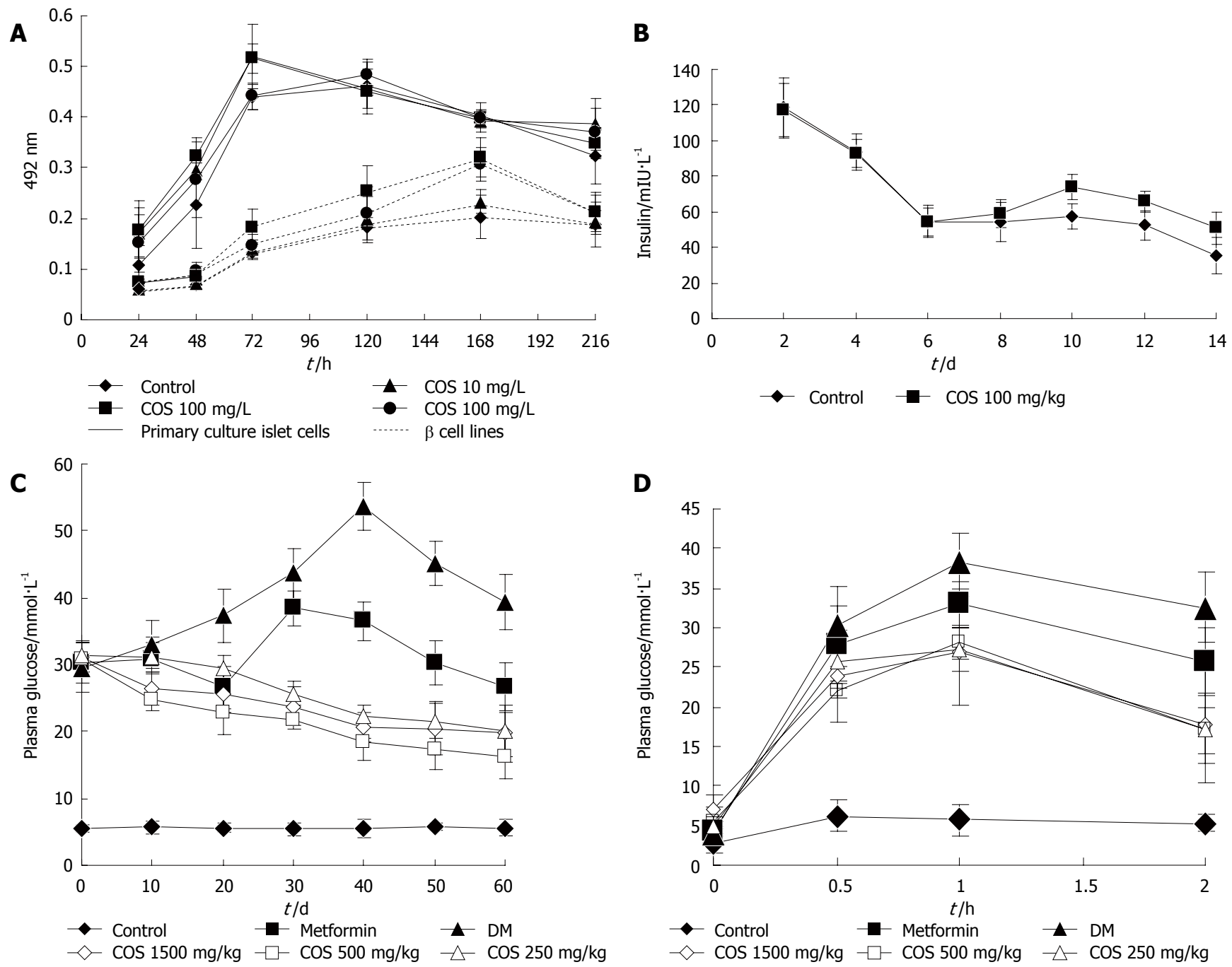

Figure 4 Effect of COS on growth phase of primary culture islet cells and $\beta$ cell lines (A), insulin release from pancreatic islet cells (B), changes in $2 \mathrm{~h}$ plasma glucose (C), and in glucose tolerance test (D) after $60 \mathrm{~d}$.

Table 1 Effect of COS on changes of plasma glucose in glucose tolerance test and AUC after $60 \mathrm{~d}(n=9$, mean \pm SD $)$

\begin{tabular}{|c|c|c|c|c|c|c|c|}
\hline \multirow[t]{2}{*}{ Group } & \multirow{2}{*}{$\begin{array}{l}\text { Concentration } \\
\mathrm{mg} / \mathrm{kg}\end{array}$} & \multicolumn{4}{|c|}{ Plasma glucose tolerance $/ \mathrm{mmol} / \mathrm{L}$} & \multirow{2}{*}{$\begin{array}{c}\text { AUC } \\
\mathrm{mmol} / \mathrm{L}\end{array}$} & \multirow{2}{*}{$\begin{array}{c}\text { AUC } \\
\%\end{array}$} \\
\hline & & $\mathbf{O H}$ & $0.5 \mathrm{~h}$ & $1 \mathrm{~h}$ & $2 \mathrm{~h}$ & & \\
\hline Control & - & $2.75 \pm 1.14^{b}$ & $6.27 \pm 1.99^{\mathrm{b}}$ & $5.78 \pm 1.99^{\mathrm{b}}$ & $5.34 \pm 1.06^{b}$ & $21.66 \pm 6.18^{\mathrm{b}}$ & 17.69 \\
\hline Met & 200 & $4.42 \pm 1.72$ & $28.01 \pm 4.71$ & $32.98 \pm 2.98$ & $25.64 \pm 4.26$ & $105.33 \pm 3.74$ & 86.05 \\
\hline DM & - & $4.08 \pm 1.40$ & $30.20 \pm 5.14$ & $38.41 \pm 3.41$ & $32.54 \pm 4.41$ & $122.40 \pm 12.05$ & 100 \\
\hline COS-H & 1500 & $7.01 \pm 1.99$ & $23.88 \pm 5.86$ & $27.04 \pm 6.81^{\mathrm{b}}$ & $17.88 \pm 7.41^{\mathrm{b}}$ & $85.79 \pm 23.90^{\mathrm{b}}$ & 70.09 \\
\hline COS-M & 500 & $5.54 \pm 1.77$ & $22.05 \pm 0.79^{\mathrm{a}}$ & $28.17 \pm 2.19^{b}$ & $17.01 \pm 3.00^{\mathrm{b}}$ & $84.08 \pm 5.93^{b}$ & 68.69 \\
\hline COS-L & 250 & $5.03 \pm 0.51$ & $25.62 \pm 3.28$ & $27.18 \pm 2.72^{\mathrm{b}}$ & $17.17 \pm 4.42^{\mathrm{b}}$ & $86.07 \pm 8.06^{\mathrm{b}}$ & 70.32 \\
\hline
\end{tabular}

${ }^{\mathrm{a}} P<0.05,{ }^{\mathrm{b}} P<0.01$ vs DM group.

of food ${ }^{[2,21]}$, and also have various potential applications in agricultural industry ${ }^{[5]}$. Chemical and enzymatic methods are widely used to produce COS and chemical hydrolysis is more commonly used. However, chemical hydrolysis has some drawbacks to be commercialized, due to the production of some toxic compounds, higher risk associated with environmental pollution, and lower production yields. COS prepared by acid hydrolytic methods cannot serve as bioactive materials in general due to the possible contamination of toxic chemical compounds. Therefore, lack of proper technology for large-scale manufacture of COS with desired molecular weights has made its use difficult in human beings in the past years. Enzymatic processes which are generally carried out in batch reactors are preferred to chemical methods. This is due to minimized adverse chemical modifications of products during enzymatic hydrolysis and promotion of their biological activities. The properties of COS, such as DP, DA, charge distribution and nature of chemical modification in the molecules strongly influence its 
observed biological activities. Therefore, molecular weight is considered a principal characteristic of COS that highly correlates to their biological activities. We have successfully obtained highly deacetylated $(90 \%)$ chitooligosaccharides with a molecular weight of $1200 \mathrm{u}$ by enzymatic hydrolysis and investigated its effect on the proliferation of pancreatic islet cells and release of insulin, lowering $2 \mathrm{~h}$ plasma glucose and normalizing oral glucose tolerance in vivo and in vitro.

Type 2 diabetes characterized by peripheral insulin resistance followed by failure of compensation for pancreatic $\beta$ cells and ultimately frank hyperglycemia ${ }^{[22]}$, is traditionally considered discrete pathophysiological lesions. Proliferation of pancreatic $\beta$ cells is slow and has a limited potential for regeneration $(<1 \%$ of the cells enter mitosis over $24 \mathrm{~h}$ in the adult state). Pancreatic $\beta$ cells maintain the blood glucose concentration within a narrow range by modulating insulin secreting rate in response to the glucose levels in blood. Proper insulin secretion requires the coordinated functioning of numerous $\beta$ cells that form pancreatic islets. This coordination depends on a network of communication mechanisms whereby $\beta$ cells interact with extracellular signals and adjacent cells via connexin channels. The structure and function of primary culture islet cells and $\beta$ cell lines were observed under inverted phase contrast microscope, and the viability of pancreatic islet cells and $\beta$ cell lines was determined by MTT colorimetric assay indirectly in our study. In order to ensure adequate access of COS to pancreatic islet cell surfaces, we performed COS-stimulated insulin release experiments using monolayer cultures of rat islets. The results indicated that all concentrations of COS could markedly increase the viability of pancreatic islet cells. COS at the concentration of $100 \mathrm{mg} / \mathrm{L}$ effectively accelerated the proliferation of pancreatic islet cells and had direct effects on pancreastic $\beta$ cells and release of insulin. Exposure of primary culture pancreatic cells to COS $(100 \mathrm{mg} / \mathrm{L})$ could continuously increase the secretion of insulin from 6 to $14 \mathrm{~d}$, as compared to the normal control group.

To study the specific role of COS in endocrine pancreatic function, we performed in vivo experiments of islet function in STZ-DM mice and measured the $2 \mathrm{hPG}$ and OGTT. Fasting plasma glucose and random plasma glucose used to be measured as the standard about the effect of lowering the plasma glucose. However neither fasting plasma glucose nor random plasma glucose can represent the actual glucose tolerance and insulin action $^{[23-25]}$. The gold standards for assessment of insulin action and glucose homeostasis are the euglycemic, hyperinsulinemic and hyperglycemic clamp studies ${ }^{[26-28]}$. Clinically, single-value glucose determinations are probably the most commonly used marker of glucose homeostasis. Assessment of glucose tolerance in a clinical setting has traditionally been conducted using the glucose tolerance test ${ }^{[29,30]}$. Since $2 \mathrm{~h}$ plasma glucose is far more sensitive than fasting plasma glucose, we chose $2 \mathrm{~h}$ plasma glucose and oral glucose tolerance test as the standard to evaluate the effect of chitooligosaccharides in STZ -induced diabetic rats.

Our findings suggest that all concentrations of chitooligosaccharides can decrease $2 \mathrm{hPG}$ in $60 \mathrm{~d}$. The best effect was observed in the medium dosage $(500 \mathrm{mg} / \mathrm{kg}$ ) treatment group, with the plasma glucose level decreased to $16.14 \mathrm{mmol} / \mathrm{L}$ compared to the DM group $(P<0.01)$. The medium dosage of chitooligosaccharides also had the best effect on glucose tolerance, accounting for $68.69 \%$ of the area under the DM group curve. The mechanism of chitooligosaccharides in decreasing the plasma glucose is perhaps due to the following reasons. Chitooligosaccharide is an alkaline, which can increase the $\mathrm{pH}$ values in the body fluid and the sensitivity of insulin. Chitooligosaccharides can regulate the function of the endocrine system, and reduce the secretion of insulin to normal, thus maintaining the normal metabolism of plasma glucose. Chitooligosaccharides can promote the proliferation of $\beta$ cells and recovery of the function of damaged $\beta$ cells.

Insulin is the primary hormone that regulates glucose uptake in mammals. In addition, a recent study demonstrated that insulin resistance itself itself at the level of $\beta$ cells may contribute to the failure of pancreatic compensation, suggesting a theory for the pathogenesis of type 2 diabetes $^{[31]}$. Indeed, mice with STZ -induced damage in $\beta$ cells lose their ability to respond adequately to glucose stimulation and have progressive glucose intolerance. In the present study, we demonstrated that patients treated with COS had a normal $\beta$ cell hyperplastic response to insulin resistance, with their $2 \mathrm{hPG}$ and urine glucose decreased, and the disorders of glucose tolerance normalized, indicating that COS play an important role in maintenance of glucose homeostasis in vivo.

In conclusion, COS possess various biological activities and can be used in the treatment of diabetes mellitus. COS can increase insulin secretion of pancreatic cells and improve the overgrowth of $\beta$ cells and isolated pancreatic islet cells, decrease the $2 \mathrm{hPG}$, and normalize the disorders of glucose tolerance in STZ-induced diabetic rats in vivo. Further study should be directed towards understanding their molecular mechanisms.

\section{ACKNOWLEDGMENTS}

We thank Mrs. Lie-Huan Chen for her help in revising this paper.

\section{COMMENTS}

\section{Background}

Chitin and chitosan can be isolated from different sources, crab and shrimp shell wastes are currently utilized as the major industrial source of biomass for the large-scale production of chitooligosaccharide (COS). Several methods have been recently used to prepare COS, and enzymatic preparation methods capture a great interest due to their safety and non-toxicity. COS possesses various biological activities and has been shown to be particularly useful in many fields. However, little attention has been paid to its activity in diabetes mellitus and related mode of action.

\section{Research frontiers}

Type 2 diabetes is characterized by peripheral insulin resistance followed by failure of compensation for pancreatic $\beta$ cells and ultimately hyperglycemia. Type 2 diabetes is traditionally consodered discrete pathophysiological lesions. The proliferation of pancreatic $\beta$ cells is slow with a limited potential for regeneration $(<1 \%$ of the cells enter mitosis over $24 \mathrm{~h}$ in the adult state). Pancreatic $\beta$ cells maintain the blood glucose concentration within a narrow range by modulating insulin secreting rate in response to the glucose levels in blood. Proper insulin 
secretion requires the coordinated functioning of numerous $\beta$ cells that form pancreatic islets. This coordination depends on a network of communication mechanisms whereby $\beta$ cells interact with extracellular signals and adjacent cells via connexin channels. Our study indicated that COS could increase insulin secretion of pancreatic cells and improve the overgrowth of $\beta$ cells and isolated pancreatic islet cells, and decrease 2hPG, normalize the disorders of glucose tolerance of STZ-induced diabetic rats in vivo.

\section{Innovations and breakthroughs}

Soluble chitooligosaccharides with lower molecular weight were prepared by enzymatic hydrolysis of chitosan with $t$ chitosanase. Enzymatic processes are generally carried out in batch reactors and are preferred to chemical methods. Our study indicated that $\operatorname{COS}$ could increase insulin secretion of pancreatic cells and improve the overgrowth of $\beta$ cells and isolated pancreatic islet cells, decrease the $2 \mathrm{hPG}$, and normalize the disorders of glucose tolerance of STZ-induced diabetic rats in vivo.

\section{Applications}

COS possesses various biological activities and can be utilized in a number of industries. Unlike high molecular weight chitosan, COS which is readily soluble in water due to its shorter chain and free amino groups in D-glucosamine units and easily absorbed through the intestine, can quickly get into the blood flow and has systemic biological effects in the organism. However, lack of proper technology for large-scale manufacture of COS with desired molecular weights has made its use difficult in human beings in the past years. Enzymatic processes which are generally carried out in batch reactors are preferred to chemical methods. This is due to minimized adverse chemical modifications of products during enzymatic hydrolysis and its biological activities. We have successfully obtained highly deacetylated $(90 \%)$ chitooligosa-ccharide with a molecular weight of $1200 \mathrm{u}$ by enzymatic hydrolysis and investigated its effect on the proliferation of pancreatic islet cells and release of insulin, lowering the $2 \mathrm{~h}$ plasma glucose and normalizing the oral glucose tolerance in vivo and in vitro. Our study indicate that COS could increase insulin secretion of pancreatic cells and improve the overgrowth of $\beta$ cells and isolated pancreatic islet cells, and decrease the $2 \mathrm{hPG}$, normalize the disorders of glucose tolerance in STZ-induced diabetic rats in vivo.

\section{Terminology}

Chitin, chitosan and chitooligosaccharides: Chitin is a natural polymer, the second most abundant organic resource on the earth next to cellulose. Chitosan is a polycationic copolymer consisting of $\beta$-1, 4-linked 2-acetamido-D-glucose and $\beta$-1, 4-linked 2-amino-D-glucose units. Both chitin and chitosan are copolymers of $\beta$ (1-4) linked Nacetyl- $\beta$-glucosamine and glucosamine units. The proportion of $\mathrm{N}$-acetyl-glucosamine units in total number of units determines the degree of deacetylation. The degree of deacetylation has an inverse relationship with the number of $\mathrm{N}$-acetyl-glucosamine units, thus deacetylation of chitosan is achieved by removing Nacetyl group. In chitosan, the degree of deacetylation is higher than $50 \%$. Chitooligosaccharide obtained by hydrolysis or degradation of chitosan, is not only water-soluble but also more effective than chitosan. NIT-1 cell line: NIT-1 cell line, a widely used $\beta$ cell line in insulin secretion studies, is established from non-obese diabetic (NOD) mice transgenic for the SV40 T antigen under control of the insulin promoter; Streptozotocin (STZ): 2-deoxy-2-(3-methyl-3-nitrosourea)$1-D-g l u c o p y r a n o s e$ is actively transported into pancreatic $\beta$ cells via the Glut-2 glucose transporter. It reacts at many sites in DNA but in particular at the ring nitrogen and exocyclic oxygen atoms of the DNA bases, predominantly producing 7-methylguanine, 3-methyladenine (3-meA), and 06-methylguanine adducts.

\section{Peer review}

This is a good descriptive study in which authors analyzed the antidiabetic effects of chitooligosaccharide (COS) on proliferation of pancreatic islet cells in streptozotocin-induced diabetic rats. The results are interesting and suggest that COS is a potential therapeutic substance that could be used in the treatment of diabetes mellitus. The authors also studies the interesting questions about the molecular mechanism involved in COS biological activity.

\section{REFERENCES}

1 Felt O, Buri P, Gurny R. Chitosan: a unique polysaccharide for drug delivery. Drug Dev Ind Pharm 1998; 24: 979-993

2 Suzuki K, Mikami T, Okawa Y, Tokoro A, Suzuki S, Suzuki
M. Antitumor effect of hexa-N-acetylchitohexaose and chitohexaose. Carbohydr Res 1986; 151: 403-408

3 Nishimura K, Nishimura S, Nishi N, Saiki I, Tokura S, Azuma I. Immunological activity of chitin and its derivatives. Vaccine 1984; 2: 93-99

4 Shibata Y, Foster LA, Metzger WJ, Myrvik QN. Alveolar macrophage priming by intravenous administration of chitin particles, polymers of $\mathrm{N}$-acetyl-D-glucosamine, in mice. Infect Immun 1997; 65: 1734-1741

5 Hadwiger LA, Beckman JM. Chitosan as a Component of PeaFusarium solani Interactions. Plant Physiol 1980; 66: 205-211

6 Chiang MT, Yao HT, Chen HC. Effect of dietary chitosans with different viscosity on plasma lipids and lipid peroxidation in rats fed on a diet enriched with cholesterol. Biosci Biotechnol Biochem 2000; 64: 965-971

7 Park PJ, Je JY, Kim SK. Free radical scavenging activity of chitooligosaccharides by electron spin resonance spectrometry. J Agric Food Chem 2003; 51: 4624-4627

8 Je JY, Park PJ, Kim SK. Free radical scavenging properties of hetero-chitooligosaccharides using an ESR spectroscopy. Food Chem Toxicol 2004; 42: 381-387

9 Tokoro A, Kobayashi M, Tatewaki N, Suzuki K, Okawa Y, Mikami T, Suzuki S, Suzuki M. Protective effect of N-acetyl chitohexaose on Listeria monocytogenes infection in mice. Microbiol Immunol 1989; 33: 357-367

10 Lee SH, Suh JS, Kim HS, Lee JD, Song J, Lee SK. MR evaluation of radiation synovectomy of the knee by means of intra-articular injection of holmium-166-chitosan complex in patients with rheumatoid arthritis: results at 4-month followup. Korean J Radiol 2003; 4: 170-178

11 Lin W, Hu X, Zhang W, Rogers WJ, Cai W. Hydrogen peroxide mediates defence responses induced by chitosans of different molecular weights in rice. J Plant Physiol 2005; 162 937-944

12 Vander P, V rum KM, Domard A, Eddine El Gueddari N, Moerschbacher BM. Comparison of the ability of partially $\mathrm{N}$-acetylated chitosans and chitooligosaccharides to elicit resistance reactions in wheat leaves Plant Physiol 1998; 118: 1353-1359

13 Park PJ, Je JY, Kim SK. Angiotensin I converting enzyme (ACE) inhibitory activity of hetero-chitooligosaccharides prepared from partially different deacetylated chitosans. J Agric Food Chem 2003; 51: 4930-4934

14 Zhang H, Du Y, Yu X, Mitsutomi M, Aiba S. Preparation of chitooligosaccharides from chitosan by a complex enzyme. Carbohydr Res 1999; 320: 257-260

15 Khan FA, Goforth PB, Zhang M, Satin LS. Insulin activates ATP-sensitive $\mathrm{K}(+)$ channels in pancreatic beta-cells through a phosphatidylinositol 3-kinase-dependent pathway. Diabetes 2001; 50: 2192-2198

16 Hopkins WF, Satin LS, Cook DL. Inactivation kinetics and pharmacology distinguish two calcium currents in mouse pancreatic B-cells. J Membr Biol 1991; 119: 229-239

17 Lernmark A. The preparation of, and studies on, free cell suspensions from mouse pancreatic islets. Diabetologia 1974; 10: $431-438$

18 Rocheleau JV, Head WS, Nicholson WE, Powers AC, Piston DW. Pancreatic islet beta-cells transiently metabolize pyruvate. J Biol Chem 2002; 277: 30914-30920

19 Patterson GH, Knobel SM, Arkhammar P, Thastrup O, Piston DW. Separation of the glucose-stimulated cytoplasmic and mitochondrial $\mathrm{NAD}(\mathrm{P}) \mathrm{H}$ responses in pancreatic islet beta cells. Proc Natl Acad Sci USA 2000; 97: 5203-5207

20 Tarsi R, Corbin B, Pruzzo C, Muzzarelli RA. Effect of lowmolecular-weight chitosans on the adhesive properties of oral streptococci. Oral Microbiol Immunol 1998; 13: 217-224

21 Tarsi R, Muzzarelli RA, Guzmán CA, Pruzzo C. Inhibition of Streptococcus mutans adsorption to hydroxyapatite by lowmolecular-weight chitosans. J Dent Res 1997; 76: 665-672

22 Warram JH, Martin BC, Krolewski AS, Soeldner JS, Kahn CR. Slow glucose removal rate and hyperinsulinemia precede the development of type II diabetes in the offspring of diabetic 
parents. Ann Intern Med 1990; 113: 909-915

23 Ramachandran A, Snehalatha C, Vijay V, Viswanathan M. Fasting plasma glucose in the diagnosis of diabetes mellitus: a study from southern India. Diabet Med 1993; 10: 811-813

24 Lee $\mathbf{C H}$, Fook-Chong S. Evaluation of fasting plasma glucose as a screening test for diabetes mellitus in Singaporean adults. Diabet Med 1997; 14: 119-122

25 Finch CF, Zimmet PZ, Alberti KG. Determining diabetes prevalence: a rational basis for the use of fasting plasma glucose concentrations? Diabet Med 1990; 7: 603-610

26 Hollenbeck CB, Chen N, Chen YD, Reaven GM. Relationship between the plasma insulin response to oral glucose and insulin-stimulated glucose utilization in normal subjects. Diabetes 1984; 33: 460-463

27 Hollenbeck C, Reaven GM. Variations in insulin-stimulated glucose uptake in healthy individuals with normal glucose tolerance. J Clin Endocrinol Metab 1987; 64: 1169-1173

28 Bogardus C, Lillioja S, Nyomba BL, Zurlo F, Swinburn B, Esposito-Del Puente A, Knowler WC, Ravussin E, Mott DM, Bennett PH. Distribution of in vivo insulin action in Pima Indians as mixture of three normal distributions. Diabetes 1989; 38: 1423-1432

29 Engelgau MM, Aubert RE, Thompson TJ, Herman WH. Screening for NIDDM in nonpregnant adults. A review of principles, screening tests, and recommendations. Diabetes Care 1995; 18: 1606-1618

30 Modan M, Harris MI. Fasting plasma glucose in screening for NIDDM in the U.S. and Israel. Diabetes Care 1994; 17: 436-439

31 Kulkarni RN, Winnay JN, Daniels M, Brüning JC, Flier SN, Hanahan D, Kahn CR. Altered function of insulin receptor substrate-1-deficient mouse islets and cultured beta-cell lines. J Clin Invest 1999; 104: R69-R75

S- Editor Wang J L- Editor Wang XL E- Editor Liu WF 